\title{
Göreve Yeni Başlayan Öğretmenlerin Yaşadıkları Güçlükler ${ }^{1}$ \\ Osman Tayyar ÇELIK ${ }^{2}$, Ümit KAHRAMAN ${ }^{3}$
}

- Geliş Tarihi:05.02.2020 • Kabul Tarihi: 02.05.2020 • Çevrimiçi Yayın Tarihi: 10.10.2020

\section{$\ddot{\mathbf{O} z}$}

Öğretmenlik mesleğinin ilk yılları, öğretmenlerin hem öğretim yaptığı hem de öğretmeyi öğrenmeye çalıştığı bir dönem olup aynı zamanda nasıl bir öğretmen olacaklarını da etkileyen önemli bir kariyer aşamasıdır. Bu kapsamda mesleğin ilk yıllarında karşılaşılan sorunlar üzerine uluslararası literatürde farklı ülkelerde yapılmış birçok nitel ve nicel araştırma bulunmaktadır. Bu araştırma, göreve yeni başlayan öğretmenlerin karşılaştıkları sorunları konu edinen nitel araştırma sonuçlarını bir araya getirerek sentezleyen bir meta sentez çalışmasıdır. Meta-senteze 11 farklı ülkeden 14 çalışma dâhil edilmiştir. Analizler sonucunda ilk olarak altı tema belirlenmiştir. Bunlar; resmi politikalar ve okuldaki uygulamalar, sosyal ilişkiler, öğretim uygulamaları, destek, bireysel faktörler, okul ve çevreye uyumudur. Sonraki aşamada ikinci düzey bir soyutlama yapılarak sentezler ortaya konmuştur. Bunlar; 1) teori ve uygulama uyumsuzluğu, 2) okul ve çevre bağlamı, 3) bireysel faktörlerin ve bağlamsal koşulların etkileşimidir. Araştırmada elde edilen temalar sorun alanlarını ifade ederken sentezler sorunların kaynağına ışık tutmaktadır. Son olarak belirlenen tema ve sentezler çerçevesinde öğretmenlerin mesleğin ilk yıllarında karşılaştıkları sorunlara yönelik geliştirilecek politika ve uygulamalara ilişkin önerilere yer verilmiştir.

Anahtar sözcükler: aday öğretmenler, mesleğe yeni başlayan öğretmenler, öğretmenliğin ilk yılları, gerçeklik şoku, uygulama şoku

Atıf:

Çelik, O.T. ve Kahraman, Ü. (2021). Göreve yeni başlayan öğretmenlerin yaşadıkları güçlükler. Pamukkale Üniversitesi Eğitim Fakültesi Dergisi, 51, 179 -205.doi:10. 9779/pauefd.684913.

\footnotetext{
${ }^{1}$ Bu çalışma, 19-22 Haziran 2019 tarihleri arasında Ankara'da düzenlenen 6. Avrasya Eğitim Araştırmaları Kongresi'nde (EJER 2019) sözlü bildiri olarak sunulmuştur.

2 Dr. Öğr. Üyesi, İnönü Üniversitesi, otayyarc@ @au.edu.tr, Orcid No: 000-0003-3951-7261

${ }^{3}$ Sorumlu Yazar, Dr. Öğr. Üyesi, Bilecik Şeyh Edebali Üniversitesi, drumitkahraman@gmail.com, Orcid No: 0000-00024547-6753
} 


\section{Giriș}

Eğitim, alanyazında çeşitli tanımlamaları yapılmış, insanların hayattaki becerilerini ve bilgilerini geliştirmesini sağlayan ve tüm vatandaşların erişim hakkı olan kamu hizmetidir. Eğitim hayatın her döneminde devam etse de formal eğitim okullarda sunulmaktadır. $\mathrm{Bu}$ noktada eğitimin amaçları ile okulların amaçlarının kesiştiği söylenebilir. Okulun amaçlarının yerine getirilmesini sağlayan da okulun paydaşları olan okul yöneticileri, öğretmenler ve yardımcı hizmetlilerdir. Öğretmenler de okullarda eğitim-öğretimin gerçekleşmesi konusunda çaba gösteren ve emek harcayan uzman kişilerdir. Öğretmenler bu uzmanlıklarını öğrencilerin niteliklerini ve performanslarını geliştirmek için kullanırlar. Öğretmenlik mesleği, kaynağı ve ürünü insan olduğundan, bireysel farklılıklara duyarlılı̆̆ ve aynı zamanda birçok paydaşın beklentilerini karşılamayı gerektirdiğinden zor bir meslek olarak görülebilmektedir. Bu zorluk özellikle üniversiteden yeni mezun olmuş ve mesleğin ilk yıllarını yaşayan öğretmenler için daha da belirgindir.

Öğretmen eğitiminden öğretmenlik mesleğine ilk geçiş süreci dramatik ve travmatik bir süreç haline gelebilmektedir. Bu süreç gerçeklik şoku, geçiş şoku, uygulama şoku olarak nitelendirilir. $\mathrm{Bu}$ tanımlar ideallerin gerçeklik sonucu çöküşünü tanımlamak için kullanılmaktadır (Veenman, 1984). Keltchermans ve Ballett (2002) da üniversite hayatından öğretmenliğe geçişin zorlukları ve karmaşıklığının "uygulama şoku (praxis schock)” olarak görülebileceğini belirtmiş ve bunu, öğretmenlerin sınıfta olmanın gerçekleri ve sorumlulukları ile yüzleşmeleri olarak tanımlamıştır. Uygulama şoku sadece sınıfta değil, okula uyum konusunda da ortaya çıkmaktadır (Keltchermans ve Ballett, 2002). Yaşanan bu zorluklar, alanyazında yer alan araştırmalara göre (Huberman, 1989; Kuzmic, 1994; Ritchie ve Wilson, 1993) göreve yeni başlayan öğretmenlerde katı ve kuralcı olma davranışı olarak ortaya çıkabilmektedir (Caspersen ve Raaen, 2014). Nieme (2002), göreve yeni başlayan öğretmenlerin karşılaştıkları problemlere bağlı olarak yaşadıkları bu uyum sorununu hizmet öncesi eğitimin (pre-service) öğretmen adaylarını öğretmenliğin ilk yıllarındaki karmaşıklığa hazırlayamamasına bağlamaktadır.

Göreve yeni başlayan öğretmenler arasında öğretmenlik mesleği yüksek düzeyde yıpratıcı bir meslek olarak görülmektedir (Ingersoll ve Strong, 2011; Lortie, 1975; Tyack, 1974). Mesleğin ilk yılları öğretmenlerin mesleki kimliklerini oluşturmaları için önemli bir evredir. Ancak yeni başlayan öğretmenler, günlük sınıf problemlerinin katmanlı endişeleri, okul içindeki zorlu bir bağlam ve meslek içindeki belirsiz bir bağlamda öğretmenlik 
uygulamalarını geliştirmede (Kelly, Reushle, Chakrabarty ve Kinnane 2014), öğretmenlik kimliği oluşturmada zorluk çeker. Bu zorluklar göreve yeni başlayan öğretmenlerin iş doyumlarını ve öğretmenliğe olan bağlılığını etkiler (Lam, 2014). İlk yıllarda yaşanılan bu sorunlar öğretmenlerde hayal kırıklığına motivasyon kaybına, strese, kaygıya ve tükenmişliğe yol açabilir. Ayrıca bu tür zorluklar öğretmenlerin mesleğin ilk yıllarında görevlerinden ayrılmalarına sebep olmaktadır. Örneğin Amerika'da öğretmenlerin yaklaşık \%40-50'si mesleğin ilk beş yılında görevlerinden ayrılmaktadır (Ingersoll, 2012).

Mesleğe yeni başlayan öğretmenlerin yaşadıkları zorluklara yönelik farklı ülkelerde yapılan çalışmalar (Boakye ve Ampiah, 2017; Cantu ve Martínez, 2006; Honng, 2012; Kozikoğlu ve Senemoğlu, 2018) öğretmenlerin mesleğin ilk yıllarında karşılaştıkları sorunların benzer olduğuna işaret etmektedir. Sınıfı, iş yükünü, idari talepleri yönetmek, bunlarla başa çıkabilmek için destek aramak, yeni müfredatlar ve bunlarla ilgili kaynak eksiklikleri ile ilgilenmek bunlara örnek olarak verilebilir (Dickson, Riddlebarger, Stringer, Tennant ve Kennetz, 2014). Mesleğin ilk yıllarında öğretmenler, desteğe ve yönlendirmeye ihtiyaç duyarlar. Bu dönem, mesleki bir kimlik kazanmak, mesleki gelişimi sürdürmek ve mesleğe devam edip etmeme açısından önemli bir dönemdir. Bu kapsamda göreve yeni başlayan öğretmenlerin yaşadıkları sorunların geniş bir bakış açısıyla resmini çekmek, kapsamlı bir değerlendirme ve sentez yapmak geliştirilecek politikalara, aday öğretmen yetiştirme modellerine ve uygulamalara katkı sağlayacaktır.

\section{Kavramsal Çerçeve}

Çalışanlardan kariyerlerinin başlangıcında mesleki bilgi ve becerileri öğrenmeleri ve kariyerleri boyunca mesleki gelişimlerini sürdürmeleri beklenmektedir. Diğer mesleklerdeki gibi öğretmenlik becerilerinin gelişimi de aşamalı bir süreç olarak görülmelidir (HelmsLorenz, Grift ve Maulana, 2016). Öğretmenliğin ilk yılları mesleki gelişimin bir aşaması ya da bir kariyer evresi olarak kavramsallaştırılmaktadır. Öğretmenlerin mesleki gelişim aşamalarını üçe ayırmak mümkündür. Hizmet öncesi dönem, mesleğin ilk yılları ve hizmet içi dönemdir. Hizmet öncesi dönem, teorik bilgiler ve mesleki becerilerin kazanıldığg bir aşamayken, mesleğin ilk yılları teorik ve pratiğin bütünleştirildiği ve uyum sürecinin yaşandığı dönemi ifade etmektedir. Son olarak hizmet içi dönem ise mesleğin ilk yıllarından bitişine kadar olan dönemi kapsamaktadır.

Öğretmenliğin ilk yılları bir kariyer evresi olarak da kavramsallaştırılmaktadır. Öğretmenlerin kariyer evreleri ile ilgili farklı sınıflandırmalar olmakla birlikte kariyer 
evreleri içerisinde mesleğin il yılları; kariyere giriş evresi (Bakioğlu, 1996), hayatta kalma ve işe alışma (Aydın, 2018; Huberman, 1989), eşik aşaması (Vonk, 1989) şeklinde farklı isimlerde kavramsallaştırılmaktadır. Aydın'a (2018) göre öğretmenler bu aşamada, mesleki becerilerini geliştirirler, mesleği ve öğretimle ilgili bazı temel fikirler edinerek mesleki kavramları kullanmaya başlarlar. Bu aşamanın sonunda öğretmenlerden bir vizyon sahibi olmaları çeşitli sorumlulukları üstlenmeleri ve bazı becerilere sahip olmaları beklenmektedir. Göreve yeni başlayan öğretmenler öğretmenlik mesleği için önemlidir. Bu öğretmenler mesleğin yenilenmesini temsil eder. Bu kapsamda mümkün olduğunca sorunsuz bir şekilde öğretmenliğe giriş yapmaları mesleğin çıkarına olmaktadır (Fottland, 2004).

Kariyer aşamalarının bu evresi mesleğe yeni başlayan öğretmenlerin hem öğretim yaptığı hem de öğretmeyi öğrenmeye çalıştı̆̆ bir dönem olarak açıklanmıştır. Ayrıca bu dönemin mesleğe yeni başlayan öğretmenler için yoğun bir dönem olduğu ve bu süreçteki deneyimlerinin sadece öğretmenliğe devam edip etmemelerini değil nasıl bir öğretmen olacaklarını da etkilediği ifade edilmiştir (Feiman-Nemser, 2001). Batmak ya da yüzmek (Varah, Theune ve Parker, 1986) olarak nitelendirilen bu dönem alan yazınında sosyalleşme süreci, mesleki gelişim, aday öğretmen yetiştirme programları ve aday öğretmenlerin karşılaştığı sorunlar açısından yoğun bir şekilde ele alınmaktadır. Sosyalleşme süreci olarak öğretmenliğin ilk yılları, hem öğretmenlik mesleğinin hem de yerel okul topluluğunun bilgi, beceri, değer ve normlarının edinilmesi ile karakterize edilmektedir (Alhija ve Fresko, 2010). Mesleğin değer ve normlarını öğrenen öğretmenler hem örgütle hem de mesleki değerlerle uyumlu hale gelir. Ancak mesleğin değer ve normlarını öğrenmekle birlikte öğretmenlerin ilk deneyimleri; öğretmenliğe, öğrencilere ve meslektaşlarına ilişkin inançları, değerlerini ve tutumlarını yeniden şekillendirmelerine yol açar. Sosyalleşme süreci sonucunda göreve yeni başlayan öğretmenler mesleki bir kimlik de edinirler. Bazı öğretmenler idealist bir öğretmen kişiliğine bürünürken bazı öğretmenler bir kamu görevlisi kimliğine (McCann ve Johannessen, 2004) bürünebilmektedir. Sonuç olarak öğretmenlerin mesleğin ilk yıllarındaki deneyimleri nasıl bir öğretmen kimliğine sahip olacaklarını da etkileyecektir.

Hizmet öncesi öğretmen eğitim programından mezun olanlar ne kadar başarılı olurlarsa olsunlar, göreve başladıklarında gerçek dünyanın problemleri ile karşı karşıya gelirler. Bütün mesleklerde olduğu gibi öğretmenlik mesleğinde de ilk y1l, adaptasyon veya öğrencilikten öğretmenliğe geçiş güçlüklerinin yaşandığı bir dönemdir (Korkmaz, Saban ve Akbaşlı, 2004). Öğretmenliğin ilk yıllarında karşılaşılan sorunlara yönelik araştırmaların 
uzun bir geçmişi vardır (Dropkin ve Taylor, 1963; Smith, 1950; Stouth, 1952). Veenman (1984) tarafından göreve yeni başlayan öğretmenlerin karşılaştıkları sorunlara yönelik yapılan çalışmada en yaygın olarak şu sorunlar belirlemiştir: Öğrencileri motive etme, sınıf disiplini, öğrencilerin çalışmalarını değerlendirme, bireysel farklılıkları ele alma, ebeveynlerle ilişkiler, sınıf çalışmasının organizasyonu, yetersiz materyaller. Sorunlardan bazıları konu alanıyla ilgiliyken, bazıları okula özgü, bazıları ise bireye özgü olabilmektedir (Boakye ve Ampiah, 2017).

Göreve yeni başlayan öğretmenlerin yıpranmaları, birçok ülkede ekonomik, sosyal ve eğitimsel bir sorun konusudur (Long vd., 2012). Alan yazındaki çalışmalar da aday öğretmenlerin sorunlarını göstermektedir. McCann ve Johannesen (2004) ABD’de yapmış oldukları araştırmada yeni öğretmenler için beş temel kaygı alanı belirlemiştir. Bunlar ilişki, işyükü/zaman yönetimi, alan/program bilgisi, değerlendirme ve özerklik/kontroldür. Cantu ve Martínez'in (2006) İspanya ve Meksika karşılaştırmasında her iki bağlamda da, başlangıç öğretmenlerinin akademik, örgütsel, sosyal sorunlarla karşı karşıya olduğu, ancak Meksika'daki öğretmenlerin belirtilen alanlarda daha fazla sorun algıladıkları belirlenmiştir. Sorunlar benzer olsa da sorunların sıklığı bağlamsal bazı faktörlere göre değişebilmektedir. Kozikoğlu ve Senemoğlu (2018) tarafindan Türkiye'deki aday öğretmenler üzerinde yapılan araştırma sonucunda ise aday öğretmenlerin mesleğin ilk yılında öğretimi planlama ve uygulamada, sınıf yönetiminde, toplum ile ilişkiler ve fiziksel çevreye uyumda, meslektaş, yönetici, veli ve rehber (danışman) öğretmenle ilişkilerde ve okulun fiziki altyapı eksikliklerinden kaynaklı çeşitli güçlükler yaşadıkları belirlenmiştir. Benzer şekilde başlangıç öğretmenlerinin karşılaştığı problemleri; giriş şoku, disiplini korumak, kültürel adaptasyon, öğrenci motivasyonunu sağlama, farklı öğretim yöntemlerini etkili kullanma, bireysel farklılıklara duyarlı olma, problemli öğrenci davranışlarını ele alma, yetersiz kaynak ve destek, sınıf çalışmasının organizasyonu, performans değerlendirme, yoğun iş yükü, meslektaşlarla sorunlar, okuldaki resmi dokümanları, raporları ve yazışmaları hazırlama (Darling-Hammond, 2003; Fetherston ve Lummis, 2012; Helms-Lorenz, Grift ve Maulana, 2016; Korkmaz, Akbaşlı ve Saban, 2004; Öztürk, 2016) şeklinde özetlemek mümkündür.

Öğretmenlik kariyerinin ilk yılları öğretmenlerin meslekte kalmasını (Dias-Lacy ve Guirguis, 2017), verimliliğini etkileyebilir. Bu kapsamda mesleğin ilk yıllarında öğretmenlerin karşılaştığı sorunları azaltmak, mesleki gelişimlerini sağlamak ve mesleğe uyumlarını kolaylaştırmak amacıyla birçok ülkede (Türkiye, ABD, İsrail, Hollanda vb.) adaylık eğitim programları hazırlanarak uygulanmaya başlanmıştır. Valeeva, Baklashova ve 
Latypova'a (2018) göre acemi öğretmenler için hazırlık programları, öğretmenlerin öğretmenlik uygulamalarına eşlik eden birçok öğretici, metodolojik, örgütsel, eğitimsel ve diğer zorlukların üstesinden gelmeye yardımcı olur. İlgili araştırmalarda adaylık eğitim programlarının; mesleki becerileri geliştirme (Helms-Lorenz, Grift ve Maulana, 2016), yıpranma problemlerini hafifletme (Long vd., 2012), mesleki sosyalleşme ve uyum (Alhija ve Fresko, 2010) işten ayrılma ve farklı okullara gitme olasılıklarını azaltma (Smith ve İngersol, 2004), meslekte kalma (Gujeratti, 2012) kurumsal işlemlerin öğrenilmesi (Ulubey, 2018), sınıf içi teknoloji kullanımı ve öğretimin yönetimi (Önder, 2018), karşılıklı öğrenme (Löfström ve Eisenschmidt, 2009) alanlarında acemi öğretmenlere katk1 sağladığ1 belirlenmiştir. Başta aday öğretmen yetiştirme programları olmak üzere, göreve yeni başlayan öğretmenlerin sorunlarına yönelik geliştirilecek politika ve uygulamaların başarılı olması için öğretmenlerin yaşadıkları sorunlara yönelik kapsamlı bir anlayışa ihtiyaç duyulmaktadır.

Öğretmenlerin mesleğin ilk yıllarında karşılaştıkları sorunlara yönelik farklı ülkelerde birçok araştırma (Hayes ve Chang, 2017; Caspersen ve Raaen, 2014; Gülay ve Altun, 2017; Mudzingwa ve Magudu, 2013) yapılmıştır. Bu araştırmalardan elde edilen bulgular, sonuç ve öneriler öğretmenlerin kariyerlerinin ilk evrelerinde karşılaştıkları sorunları bütüncül bir bakış açısıyla değerlendirmek için zengin veriler sunmaktadır. $\mathrm{Bu}$ kapsamda yapılacak bir araştırmanın öğretmenlerin mesleğin ilk yıllarında karşılaştıkları sorunlara yönelik geliştirilecek politika ve uygulamalara, öğretmenlere verilecek gerekli desteğin niteliğine, aday öğretmen yetiştirme programlarının geliştirilmesine katk1 sağlayacağı umulmaktadır. $\mathrm{Bu}$ düşünceden hareketle bu araştırmada, öğretmenlerin kariyerlerinin ilk yıllarında karşılaştıkları sorunlara yönelik farklı ülkelerde yapılmış nitel araştırmaların sonuçlarını sentezlemek, geliştirilecek politika ve uygulamalara yönelik önerilerde bulunmak amaçlanmıştır.

\section{Yöntem}

$\mathrm{Bu}$ araştırma göreve yeni başlayan öğretmenlerin yaşadıkları problemler ve yaşanan bu problemlere yönelik önerilerin incelendiği bir meta sentez çalışmasıdır. Meta sentez çalışmaları, daha önce konu ile ilgili yapılmış nitel araştırmaların bulgularının analizi, yorumu ve sentezlenmesi şeklinde gerçekleştirilen araştırmalardır. Noah (2017) meta analize benzeterek, meta sentezin nitel araştırmalarını meta analizi şeklinde yorumlamaktadır. Ancak meta sentezde veri kaynağı olarak nitel araştırmaların bulguları, sonuçları ve 
yorumları derinlemesine sentezlenerek bütüncül olarak ele alınır ve bu veriler nicel verilere dönüştürülmez (Konan, Çelik ve Çetin, 2018; Weed, 2005). Meta sentez bulguların toplu bir özetinden ziyade bulguların yorumlayıcı bir sentezidir (Noblit ve Haare, 1988). Meta sentez çalışmalarında öncelikle alan yazın taraması gerçekleştirilerek, meta senteze dâhil edilecek çalışmalar belirlenir. Daha sonra ise bu çalışmaların sonuçları değerlendirilerek kategori ve temalar elde edilerek yorumlanır. Son olarak ise elde edilen temalar sentezlenir ve konu ile ilgili temel alanlar belirlenir.

\section{Çalışmaların Belirlenmesi ve Verilerin Toplanması}

Meta sentez çalışmalarına bir takım işlem basamaklarından sonra başlanır. Konan, Çelik ve Çetin (2018) alanyazında yer alan çalışmalardaki (Noah, 2017; Noblit ve Hare, 1988; Sandelowski ve Barroso, 2003) basamakları örnek alarak verilerin toplanması ve çalışmaların belirlenmesinde takip edilecek süreçleri belirlemişlerdir. Bu çalışmada da aynı süreçler kullanılmıştır.

- Çalışma alanının belirlenmesi.

- Anahtar sözcüklerin belirlenmesi

- Taramanın gerçekleştirilmesi

- Dâhil etme ve hariç tutma ölçütleri belirlenerek ulaşılan her bir çalışmanın bu ölçütlere göre değerlendirilmesi.

- Değerlendirmeye alınacak çalışmalara karar verilmesi.

$\mathrm{Bu}$ çalışma, göreve yeni başlayan öğretmenlerin yaşadıkları problemlerle ilgili genel bir çerçeve sunmak üzere hazırlanmıştır. Bu nedenle çalışmada farklı ülkelerden araştırmaların yer alması için yurt içi ve yurt dışı alanyazın ilgili veri tabanlarında "göreve yeni başlayan öğretmen, acemi öğretmen" sözcükleri Türkçe ve İngilizce olarak tarama gerçekleştirilmiştir. Veri tabanları olarak TÜBİTAK ULAKBİM (Ulusal Akademik Ağ ve Bilgi Merkezi) Sosyal ve Beşeri Bilimler Veri Tabanı, Google Akademik, ERIC, EbscoHost, Web of Science veri tabanları kullanılmıştır. Yapılan tarama ile konu ile ilgili 216 yayına ulaşılmıştır.

Meta sentez çalışmalarında kullanılmak üzere yeterli çalışma sayısı hakkında alanyazında (Bondas ve Hall, 2007; Sandelowski, Docherty ve Emden, 1997; Weed, 2005; Noah, 2017) çeşitli görüşler vardır. Alanyazındaki bu görüşler dikkate alınarak ve aşağıda belirtilen ölçütler çerçevesinde 14 makale bu araştırmaya dâhil edilmiştir. Bu çalışmaların 
belirlenmesinde konunun alanı ve amacına bağlı kalınarak belirlenen ölçütler şöyle siralanabilir:

- Araştırma alanyazında kabul gören nitel yöntemlerin kullanılması

- Araştırma bulgularının verilerle desteklenmesi

- Araştırmalara tam metin olarak ulaşılmış olması

Araştırmaya dâhil edilen çalışmaları Tablo 1'de verilmiştir.

Tablo 1. Araştırmaya Dâhil Edilen Çalışmalara İlişkin Bilgiler

\begin{tabular}{|c|c|c|c|c|}
\hline Kod & Künye & Ülke & $\begin{array}{l}\text { Çalışma } \\
\text { Grubu }\end{array}$ & Veri Analizi \\
\hline A1 & Hayes ve Chang, 2017 & $\begin{array}{l}\text { GÜNEY } \\
\text { KORE }\end{array}$ & 5 & $\begin{array}{l}\text { Betimsel Analiz ve } \\
\text { içerik analizi }\end{array}$ \\
\hline $\mathrm{A} 2$ & $\begin{array}{l}\text { Dickson, Riddlebarger, } \\
\text { Stringer, Tennant ve }\end{array}$ & $\begin{array}{l}\text { BİRLEŞİK } \\
\text { ARAP }\end{array}$ & 6 & $\begin{array}{l}\text { Betimsel Analiz ve } \\
\text { içerik analizi }\end{array}$ \\
\hline A3 & $\begin{array}{l}\text { Ulvik, Smith ve Helleve, } \\
2009\end{array}$ & NORVEÇ & 9 & $\begin{array}{l}\text { Betimsel Analiz ve } \\
\text { içerik analizi }\end{array}$ \\
\hline A4 & $\begin{array}{l}\text { Mudzingwa ve Magudu, } \\
2013\end{array}$ & ZİMBABWE & 24 & $\begin{array}{l}\text { Betimsel Analiz ve } \\
\text { içerik analizi }\end{array}$ \\
\hline A5 & Temiz, 2017 & A.B.D. & 5 & $\begin{array}{l}\text { Betimsel Analiz ve } \\
\text { isoril onslizi }\end{array}$ \\
\hline A6 & $\begin{array}{l}\text { Kozikoğlu ve Senemoğlu, } \\
2018\end{array}$ & TÜRKIYYE & 33 & $\begin{array}{l}\text { Betimsel Analiz ve } \\
\text { içerik analizi }\end{array}$ \\
\hline A7 & Gülay ve Altun, 2017 & TÜRKIYYE & 14 & $\begin{array}{l}\text { Betimsel Analiz ve } \\
\text { içerik analizi }\end{array}$ \\
\hline A8 & $\begin{array}{l}\text { Gömleksiz, Kan, Biçer ve } \\
\text { Yetkiner, } 2010\end{array}$ & TÜRKIYE & 23 & $\begin{array}{l}\text { Betimsel Analiz ve } \\
\text { içerik analizi }\end{array}$ \\
\hline A9 & $\begin{array}{l}\text { McCann ve Johannessen, } \\
2004\end{array}$ & A.B.D. & 6 & $\begin{array}{l}\text { Betimsel Analiz ve } \\
\text { içerik analizi }\end{array}$ \\
\hline A10 & Aitken ve Harford, 2011 & İRLANDA & 11 & $\begin{array}{l}\text { Betimsel Analiz ve } \\
\text { içerik analizi }\end{array}$ \\
\hline A11 & $\begin{array}{l}\text { Gaikhorst, Beishuizen, } \\
\text { Doncanhnom \&r Volman }\end{array}$ & HOLLANDA & 15 & $\begin{array}{l}\text { Betimsel Analiz ve } \\
\text { içerik analizi }\end{array}$ \\
\hline A12 & Lam, 2014 & HONG-KONG & 13 & $\begin{array}{l}\text { Betimsel Analiz ve } \\
\text { içerik analizi }\end{array}$ \\
\hline A13 & $\begin{array}{l}\text { Dias-Lacy ve Guirguis, } \\
2017\end{array}$ & A.B.D. & 1 & $\begin{array}{l}\text { Betimsel Analiz ve } \\
\text { içerik analizi }\end{array}$ \\
\hline A14 & Boakye ve Ampiah, 2017 & GANA & 5 & $\begin{array}{l}\text { Betimsel Analiz ve } \\
\text { içerik analizi }\end{array}$ \\
\hline
\end{tabular}




\section{Verilerin Analizi}

Nitel verilerin analizinin, araştırmaların en çok uğraştıran basamaklarından biri olduğu söylenebilir. Analize, veri toplama ile birlikte başlanması bu aşamada yaşanacak zorlukların önüne geçebilir. Ancak nitel verilerin analiz süreçleri için belirli bir standart ya da yöntem bulunmamaktadır (Cresswell, 2013; Merriam, 2009). Bu durum meta sentez çalışmaları için de geçerlidir. Bu araştırmada da alanyazında yer alan yöntemler ışığında aşağıdaki adımlara göre (Konan, Çelik ve Çetin, 2018) analizler gerçekleştirilmiştir.

1- Verilerin okunması ve düzenlenmesi

2- Verilerin kodlanması

3- Kodların bira araya getirilerek kategorilerin oluşturulması.

4- Sentezleme (analitik temaların ortaya çıkarılması)

5- Analitik temaların sunulması ve yorumlanması

Çalışmada öncelikle araştırma kapsamında ele alınan çalışmalar okunmuş, çalışmaların künyeleri, amacı, temaları ve önerileri düzenlenerek tablo haline getirilmiştir. Ayrıca çalışmalar A1,A2,A3......, A14 şeklinde isimlendirilmiştir. İkinci aşamada çalışmalarda yer alan kodlar işaretlenmiş ve dijital ortama aktarılmıştır. Bu kodlardan benzer olanlar bir araya getirilmiş ve temaların alt yapılarının oluşturulması sağlanmıştır. Daha sonra araştırmalar tekrar incelenmiş, eklenmesi ya da çıkarılması gereken kodlarla ilgili gerekli işlemler yapılmış ve kodlama işlemi tamamlanmıştır. Sentez sürecinde öncelikle kodlar bir araya getirilmiş ve ortak temalar oluşturulmuştur. Ortak temaların bulunması ile birlikte soyut bir genelleme daha yapılarak sentezler ortaya çıkarılmıştır.

Elde edilen kodlar, temalar ve sentezler bir şekil üzerinde toplanarak bütüncül bir bakış sağlanması amaçlanmıştır. Her bir tema başlık olarak doğrudan alıntılarla desteklenerek açıklanmış ve sentezler de başlıklar halinde tartışılmıştır. Doğrudan alıntılar, çalışmanın kodu ile çalışmada yer alan katılımcının kodunun birleştirilmesi ile elde edilen kodlarla verilmiştir.

\section{Geçerlik ve Güvenirlik}

Nitel araştırma türlerine bağlı olarak geçerlik ve güvenirliğe dair ölçütlerde de farklılıklar bulunmaktadır (Merriam, 2009). Meta sentez araştırmalarında geçerlik ve güvenirliği sağlamak amacıyla araştırmacıların fikir birliği içerisinde olduğu ortak yöntemler 
bulunmamaktadır. Araştırmanın geçerliği için alan yazında ortak olarak vurgulanan (Creswell, 2013; Merriam, 2009; Neuman, 2012) üçgenleme tekniği kullanılmıştır. Üçgenleme tekniğinin veri toplama ve araştırmacı üçgenlemesi şeklinde farklı türleri bulunmaktadır. $\mathrm{Bu}$ araştırmanın veri kaynağı ikincil araştırmalar olduğundan araştırmacı üçgenlemesi yapılmıştır. Bu çerçevede her iki araştırmacı meta senteze dâhil edilen çalışmaları ayrı ayrı okuyarak kodlama yapmışlar ve temalar oluşturmuşlardır. Sonraki aşamada bu kodlar ve temalar bir araya getirilmiş alan uzmanı iki araştırmacıyla paylaşılmıştır. Kodlar üzerinde tartışılmış ve böylece temalara karar verilmiştir.

Nitel araştırmalarda güvenirlik araştırmanın tekrar edilebilirliği ile ilgili bir durumdur. Diğer bir ifadeyle süreçlerin tekrar edilmesi durumunda benzer sonuçlara ulaşabilmektir. Bu kapsamda araştırmada, meta senteze dâhil etme kriterleri ve dâhil edilen çalışmalar ve veri analizi detaylı bir şekilde rapor edilmiştir. Son olarak temaları desteklemek amacıyla meta senteze dâhil edilen çalışmalardan doğrudan alıntılar ilgili çalışmadaki koduyla sunulmuş ve teyit edilebilmesine olanak sağlanmıştır.

\section{Bulgular}

Meta senteze dâhil edilen çalışmaların incelenmesi sonucunda altı tema ve üç sentez elde edilmiştir. Araştırmalardan elde edilen kodlar, temalar ve sentezler ş̧ekil 1'de sunulmuş, başlıklar halinde açıklanarak tartışılmıştır.

\section{Temalar}

\section{Resmi politikalar ve okuldaki uygulamalar}

$\mathrm{Bu}$ tema, mesleğin ilk yıllarında öğretmenlere ilişkin resmi politikalar ve okuldaki uygulamalardan kaynaklı sorunlara odaklanmaktadır. Aday öğretmenlerin mesleğe uyumunu sağlamak amacıyla birçok ülkede başlangıç eğitimi, yetiştirme programı ya da indüksiyon adı altında hazırlık programları yapılmaktadır. Bu programların içeriğinde seminerler, gözlemler ve hizmet içi eğitimler gibi farklı uygulamalar bulunabilmektedir. Yetiştirme programları kapsamında iyi planlanmamış ya da gereksiz etkinlikler sorun olarak algılanabilmektedir. Ayrıca okul yönetiminin göreve yeni başlayan öğretmenler üzerindeki sıkı denetimi özerklik kapsamında öğretmenler tarafından sorun olarak algılanmaktadır. Önemli bir problem de deneyimli öğretmenlermiş gibi göreve yeni başlayan öğretmenlere sınıf, nöbet vb. görevler verilmesidir. Bu yoğun iş yüküyle birlikte okul yönetimince de yeni başlayan öğretmenlere ekstra görevler verilebilmektedir. Meta senteze dâhil edilen 
çalışmalarda (Mundzigwa ve Magudu, 2013) bu tema kapsamında sorun olarak görülen diğer hususlar düşük maaş ve kaynak (ders araç gereç) eksikliğidir. Ücret politikaları ülkeden ülkeye değişmekle birlikte kaynak eksikliği genel olarak kırsal bölgelerde bir sorun olarak ortaya çıkmaktadır. Bu tema kapsamında meta senteze dahil edilen çalışmalardan doğrudan alıntılar aşağıda sunulmuştur.

"Illk yılımda bana oldukça yorucu fazlaca idari görev verdiler. Tabii ki o zamanlar başka şansım olmadı̆̆ını anlamıştım. Ama yine de keşke o kadar iş yükünden dolayı bıkmış olmasaydım." (A1-Ms. Jeong).

"Hizmet içi ĕgitimler gerektiği gibi ciddi verilmediği için her gelen müfettişlerden azar işitir olduk. İlçe milli eğitimin yazışmalar hakkında doğuştan bilgi sahibi olduğumuzu sanmaları ve bilgilendirme konusunda çok aciz olmaları yetki yazışma ve sorumlulukları să̆dan soldan ya da yönetmeliklerden ögrenerek çözmeye çalıştık." (A8-M16E).

"Sabah 7'den akşam altı buçuğa kadar okulda çalıştım. Geceleri derslerimi hazırlardım. Önceki kariyerimde çok çalışmaya alışmıştım, ama öğretmen olarak pek çok yeni şey yapmalısınız ve çok fazla sorumluluk taşıyorsunuz." (A11).

\section{Sosyal ilişkiler}

$\mathrm{Bu}$ tema göreve yeni başlayan öğretmenlerin okul içi ve paydaşlarla ilişkilerinden kaynakl1 sorunlara odaklanmaktadır. Bu sorunlar genellikle okul iklimi ve kültürüyle ilişkiliyken yönetici ve meslektaşların olumsuz tutum ve davranışları göreve yeni başlayan öğretmenler tarafından sorun olarak algılanmaktadır. İlişkiler kapsamında ebeveynlerle de sorunlar yaşanabilmektedir. Ailelerin yoğun beklentileri öğretmen adaylarının bu beklentilere cevap verememesi, henüz yeni olduğundan ilişkileri yönetmede deneyimsizliği ebeveynlerle sorunlar yaşanmasına sebep olabilmektedir. Okul ortamındaki sinik tutumlar örgüte ya da meslektaşlara yönelik düşmanca tutum ve davranışları ifade etmektedir. Bu sinik davranışlar aynı zamanda mobbing ya da ayrımcılık olarak da ortaya çıkabilmektedir. 


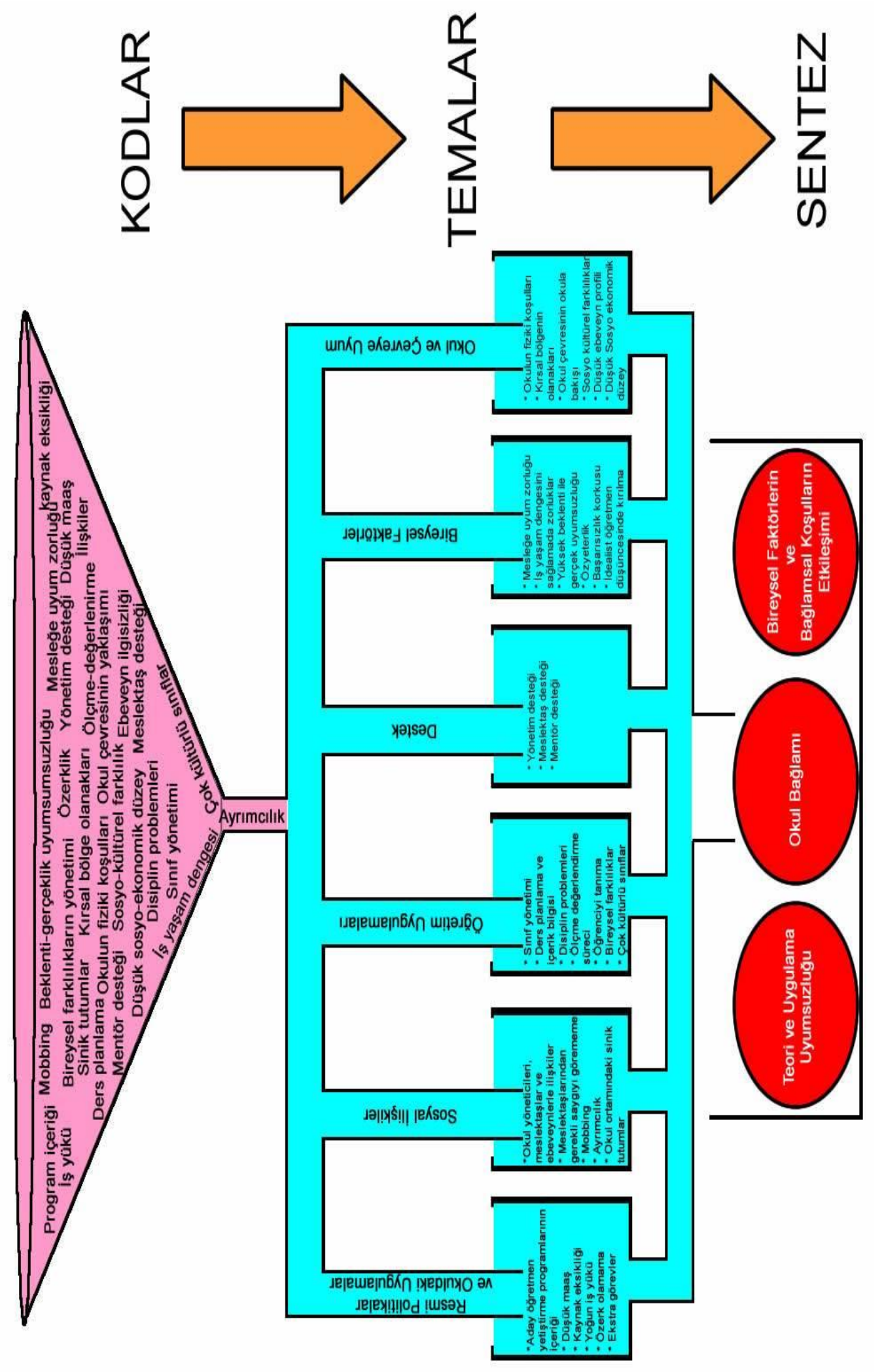

Şekil 1. Kodlar, temalar ve sentezler 
O.T. Çelik ve Ü. Kahraman/ Pamukkale Üniversitesi Eğitim Fakültesi Dergisi, 51, 179-205, 2021

$\mathrm{Bu}$ olumsuz durumlar göreve yeni başlayan öğretmenlerin sayg1 ihtiyaçlarını karşılayamamasına neden olmakta, itibar algılarına da zarar verebilmektedir. $\mathrm{Bu}$ tema kapsamında meta senteze dâhil edilen çalışmalardan doğrudan alıntılar aşağıda sunulmuştur.

"Bazen veliler numaramı istiyor ama onlara vermiyorum, özel hayatımı korumak istiyorum ve onlarla hafta sonlarl veya tatilimde konuşmak istemedim, bu yüzden bu işleri sosyal hizmet uzmanının yapmasını sağladım, ve veliler gün boyunca her zaman gelebilirler." (A2).

"Bilirsiniz bazen kazalar oluyor. Bununla ilgili her şeyi tam olarak bilemezsiniz ve kontrol edemezsiniz. Çünkü orada değilsiniz. Bazen veliler içeri girerler. Çocuğun ynă̆ını göstererek bu şey de nedir, bu çizik nasıl oldu? Diye sorarlar. Velilerin baskı yaptı̆̆ tek şey budur." (A5 -Sally).

"Bir meslektaşımla aram bozuldu ve insanların artık benimle konuşmadıklarını fark edemedim. Bu çok zordu çünkü tüm yeni öğretmenler aynı alanda birlikte otururlar. Çok üzgündüm çünkü hakkımda bir karar verdiklerini hissettim." (A10-NQT5).

\section{Öğretim uygulamaları}

$\mathrm{Bu}$ tema göreve yeni başlayan öğretmen adaylarının akademik bilgi ve becerilerini uygulamaya yansıtmada karşılaştıkları problemlere odaklanmaktadır. Öğretmenlik, mesleki bilgi ve becerilerin yanında bunların uygulamaya yansıtılmasını gerektirmektedir. $\mathrm{Bu}$ kapsamda göreve yeni başlayan öğretmenlerin, sınıf yönetimi, planlama, ölçme ve değerlendirme, öğrenciyi tanıma, bireysel farklılıkları yönetme ve problemli öğrencilerle başa çıkma gibi alanlarda teorik bilgilerini uygulamaya aktarmada zorlandıkları söylenebilir. Bunların yanında önemli bir sorun da göreve yeni başlayan öğretmenlerin müfredata ve müfredat içeriğine yönelik bilgi eksikliğidir. Öğretmenler bu bilgi eksikliğini kendileri için sorun olarak görmektedir. Bu tema kapsamında meta senteze dâhil edilen çalışmalardan doğrudan alıntılar aşağıda sunulmuştur. 
"En büyük zorluklardan biri, farkl ülkelerden gelen anadili Norveççe olmayan ve farkl geçmişe sahip 15 kişilik bir sınıftan sorumlu olmaktı." (A3-6).

“Ístanbul'da ögretmenlik yaptığımdan dolayı sinıfta Türkiye'nin her yerinden, birbirinden farklı kültürlerden gelmiş ögrenciler var. Bu da daha önce yeterli tecrübeye sahip olmadığımdan sınıf hâkimiyetinde sıkıntı yaratmaktaydl." (A6).

"Nasıl sorular hazırlamam gerektiğini bildiğimi düşünüyorum fakat bazen soruların güçlük derecesini kestiremiyorum. Bazen hazlrlarken kolay olduğunu düşündüğüm bir sınavda ögrencilerin başarısız olduğunu görüyor ve beklemediğim sonuçlarla karşılaşıyorum. Bunun sebebi benim ögrrencileri yeterince tanımamam ya da onların yeteri kadar konulart tekrar etmemeleri olabilir." (A7-Ö7).

"Sınıf yönetimimi geliştirmem gerek. Sınıftaki 33 ögrencim çok şen şakrak.” (A13).

\section{Destek}

$\mathrm{Bu}$ tema göreve yeni başlayan öğretmenlerin yönetimden ve meslektaşlardan göremediği destek eksikliği sorununa odaklanmaktadır. Mesleğin ilk yıllarında karşılaşılan sorunların üstesinden gelmek, uyum sağlamak ve mesleki bir kimlik kazanmak için öğretmenler mesleki paylaşımlara psikolojik ve sosyal desteğe ihtiyaç duyaralar. Bu kapsamda, genel olarak mentörlük uygulamaları ile göreve yeni başlayan öğretmenlere destek sağlanmaya çalışılmaktadır. Ancak mentörden veya mentörlük sisteminden kaynaklı sebeplerle öğretmenler yeterli destek alamayabilmektedir. Bunun yanında destek, yönetim ve meslektaş desteğini kapsayan çok yönlü bir süreçtir. Meslektaşlarından ve yönetimden yeterli desteği göremeyen öğretmenlerin sorunlar yaşaması ya da sorunların üstesinden gelmede zorlanma ihtimali yüksektir. Bu tema kapsamında meta senteze dahil edilen çalışmalardan doğrudan alıntılar aşağıda sunulmuştur.

"Rehber öğretmenim başka bir branştandl. Evrak işlerinde her türlü sorumun cevabını rahatlıkla alabildim 
O.T. Çelik ve Ü. Kahraman/ Pamukkale Üniversitesi Eğitim Fakültesi Dergisi, 51, 179-205, 2021

ama kendi branşımla ilgili, ögrretimle ilgili destek alamadım. Sınıf içi etkinliklerle ilgili neyi, nasıl yapacă̆ıma ilişkin pek bir destek alamadım." (A6)

“O kişiye hiçbir şekilde tekrar gitmezdim (Müdür Yardımcısı). Sorunlu bir ögrencim olsaydı başka kime gideceğimi bilmiyordum. Kendi başınıza hayatta kalmaya çalışmak çok büyük bir şey. Personel üzerinde izolasyon (tecrit) duygusu var ve kime gideceğinizi bilmiyorsunuz "(A10, NQT2)

“Aslında, hepsini kendiniz çözmelisiniz... İlk yılımda bu kadar çok sorun yaşamamın ana nedeni buydu. Beni esasen kendi inancıma biraktılar. Sik sik [destek ya da denetim] istediğim halde kimse bana rehberlik etmedi (A13).

\section{Bireysel faktörler}

$\mathrm{Bu}$ tema çevresel faktörlerin etkisiyle birlikte kişisel faktörlerin de kaynaklık ettiği sorunlara odaklanmaktadır. Göreve yeni başlayan öğretmenlerin yaşadıkları sorunların kaynağı farklı olmakla birlikte kişisel özellikleri de sorunlara kaynaklık edebilmektedir. Nitekim bu tema altında belirtilen düşük özyeterlik, başarısızlık korkusu, iş yaşam dengesini sağlamak, mesleğe uyum gibi sorunlar bireylerin uyum kapasitesi, sorunların üstesinden gelmeye ve yeterliklerine ilişkin inançları ile yakından ilişkilidir. Bu tema kapsamında meta senteze dahil edilen çalışmalardan doğrudan alıntılar aşağıda sunulmuştur.

"Her gün, hafta sonlarl bile internete giriyorum. Durmam gerek, çünkü beni yiyip bitiriyor. Öğrenciler bana akşam, cuma gecesi veya cumartesi sabahı bir eposta gönderdiğinde, cevap veriyorum. Bu benim hatam."(A3-9).

"Bu bir vahşi hayvanların kafesine atılmak gibi bit şey. O ilk hafta, Aman Tanrım! Bu çocuklar farklı. Onlar olacağını düşündüğüm şey değillerdi, hem de hiç. Birisi "biz bunu yapmayız” ya da “yürü" dese, onların yapacă̆ını düşündüm. (A5 Lisa). 


\section{Okul ve çevreye uyum}

$\mathrm{Bu}$ tema göreve yeni başlayan öğretmenlerin okul ve çevresine uyumunu zorlaştıran alanlara odaklanmaktadır. Bu kapsamda okulun fiziki koşulları, bölgenin olanakları, çevrenin okula bakışı, ailelerin sosyo-ekonomik düzeyleri ve okula ilgisi öğretmenlerin uyumunu zorlaştıran faktörler olarak öne çıkmaktadır. Ayrıca öğretmenler yakından tanımadı̆̆ı, farklı sosyo kültürel özelliklere sahip bölgelerde de uyum sorunuyla karşılaşabilmektedir. Bu tema kapsamında meta senteze dâhil edilen çalışmalardan doğrudan alıntılar aşağıda sunulmuştur.

“Birçok yönden uyumda zorluk çekiyorum. Toplumun
yaşayış şekli, çocuklarını büyütme tarzları, önem
verdikleri konular itibariyle benim benimsediğim şeyler
değil.” (A6).
"Ulaşım sorunumuz var; köyden ilçeye veya ile düzenli
taşıma yapılamıyor. Su sorunumuz var; şebeke suyu
yeterli olmadığından, suyumuzu kovalarla temin etmek
zorunda kalıyoruz. Elektrik sorunumuz var ;köyde sürekli
elektrik kesintisi yaşanıyor.” (A8-M20E).

\section{Meta sentez}

$\mathrm{Bu}$ başlık altında, meta senteze dâhil edilen araştırmalardan elde edilen temaların, araştırma sonuçları ve önerilerinin ikinci düzey soyutlaması sonucu elde edilen sentezlere yer verilmiştir. Bu kapsamda; teori ve uygulama farklılığı, okul bağlamı, öğretmen yetiştirme politikaları olmak üzere üç sentez elde edilmiştir. Bu sentezler mesleğe yeni başlayan öğretmenlerin yaşadıkları sorunların kaynağına 1şık tutmaktadır. Sentezler aynı zamanda meta sentez çalışmalarının sonucunu ifade etmektedir. Yapılan sentezlemelere ilişkin çok yönlü değerlendirmeler, ilgili araştırma sonuçları ve görüşler başlıklar halinde aşağıda tartışılmıştır.

\section{Teori ve uygulama uyumsuzluğu}

Öğretmenlik mesleğinin ilk kariyer evresi lisans eğitimine girişle başlamaktadır. $\mathrm{Bu}$ dönem mesleğe ilişkin teorik bilgilerin kazanıldığı, uzmanlaşmanın sağlandığı formal bir eğitim sürecini kapsamaktadır. Bu sürenin sonunda göreve yeni başlayan öğretmenlerden, müfredat, çocuk, öğrenme ve pedagoji anlayışlarını pratik sınıf etkinliklerine dönüştürmeleri beklenmektedir (Fottland, 2004). Öğretmen adayları da bir mesleğin gerektirdiği bilgi ve becerilere sahip olduklarını düşünerek biran önce bunları uygulama heyecanı içerisindedir. 
Schuck, Aubusson, Buchanan ve Russell (2012) öğretmen adaylarının öğretmenliğin ilk aylarındaki yaşadıkları bu duygu ve düşünceleri şöyle ifade etmiştir.

“...Öğretmenliğin ilk ayları, göreve yeni başlayan öğretmenler için hız treninde yolculuk yapmak gibidir. Bir okulda göreve başladıkları için çok mutlu olan öğretmenler sınıfta ders anlatmayı dört gözle beklemektedirler. Sinıfta yapacakları etkinlikleri ve öğrencileri motive edecek ilk dersleri planladıklarını düşünerek mutlu günler geçirirler.”

Göreve yeni başlayan öğretmenlerin bu heyecanlarıyla birlikte, başarmayı hedefledikleri idealler ile sınıf gerçekleri arasındaki tutarsızlıklar, yetersizlikler ve kendini hazır hissetmeme duyguları aday öğretmenlerin yoğun bir mücadele içerisine girmesini gerektirir (Aydın, 2018). Öğretmenlerin karşılaştıkları teori ve uygulama arasındaki bu uyumsuzluk alan yazınında “ uygulama şoku” (Keltchermans ve Ballett, 2002) olarak ifade edilmektedir. Teori ve uygulama arasındaki farklılıklar göreve yeni başlayan öğretmenlerde kaygıya yol açmaktadır. Sandlin, Young ve Karge (1993) göre teorik bilgileri uygulamayla entegre edemeyen öğretmenler üç alanda kaygı yaşamaya başlarlar. Bunlar; mesleğe devam edip edemeyecekleri hakkında kaygı, gerçek öğretmenlik görevlerini yerine getirememe konusunda kaygı ve son olarak kendi öğretme yetenekleri ve öğrencilerin öğrenmeleri üzerinde etkide bulunma konusunda yaşadıkları kaygıdır. Bu kapsamda özellikle lisans eğitimi sürecinde uygulama ağırlıklı programlara dikkat çekilmektedir (Gujarati, 2012; Helms-Lorenz, Van de Grift ve Maulana, 2016). Nitekim öğretmenlik, mesleğin gerektirdiği bilgileri uygulamayla bütünleştirmeyi gerektiren bir meslektir. Fantilli ve McDougall (2009), hizmet öncesi eğitim kurumlarının, öğretimin gerçekliğini yansıtan alanlarda eğitim sunarak öğretmen adaylarını mesleğe daha iyi hazırlayabileceğini ifade etmiştir. Teori ve uygulama arasındaki uyumsuzluğu ortadan kaldırmak için aday öğretmenlerin, özellikle lisans eğitimi sürecinde gerçek sınıf ortamlarında öğretim uygulamaları gerçekleştirmeleri, ileride karşılaşabilecekleri muhtemel sorunlarla önceden yüzleşmeleri, hem mesleki gelişimlerine katkı sağlayacak hem de güçlendirmeleri gereken yönlerini ortaya çıkaracaktır. Bu kapsamda hizmet öncesi eğitimde uygulamaya ağırlık vermek göreve yeni başlayan öğretmenlerin gerçeklik şoku yaşamalarını azaltabilir. Bir köprü işlevi görmesi açısından birçok ülkede (Türkiye, İsrail, Hollanda, ABD vb.) adaylık eğitim programları uygulanmaktadır. Teoriye dayalı hizmet öncesi eğitimden sonra uygulama ağırlıklı aday öğretmen yetiştirme programları da öğretmenlerin yaşadıkları uygulama şokunu azaltabilir. 


\section{Okul ve çevre bağlamı}

Okul içi ve çevreyle ilişkilerin niteliği, görev yapılan bölgenin koşulları bu sentez altında bir araya getirilmiştir. Öğretmenlerin göreve başladıkları yerin kültürü, coğrafi şartları, ailelerin sosyo-ekonomik düzeyi yaşanılan sorunların kaynağı olabilmekte, ayrıca sorunların şiddetini de etkileyebilmektedir. Nitekim Kozikoğlu ve Senemoğlu (2018) tarafindan yapılan araştırmada aday öğretmenlerin bulundukları bölgeye yabancı olmaları, kültür, dil, insanların sosyo-ekonomik düzeyi, eğitim düzeyi, önemsedikleri konular vb. gibi durumlar bakımından farklılıkların olması aday öğretmenlerin toplumla ilişkilerde zorlanmalarının önemli nedenleri olduğu belirlenmiştir. Zetlin, MacLeod ve Kimm (2012) tarafindan yapılan araştırmada ise farklı okul düzeylerinde ve bölgelerde (şehir, kasaba vb.) öğretmen adaylarının karşılaştığı sorunların farklılaştığı tespit edilmiştir. Meta senteze dâhil edilen araştırmalarda (Dias-Lacy ve Guirguis, 2017; Kozikoğlu ve Senemoğlu, 2018; Mudzingwa \& Magudu, 2013 da bölge koşulları, ailelerin okula ilgisi ve sosyo-ekonomik sorun kaynağı olarak ele alınmıştır.

Önemli bir konu da okulun kültürü ve iklimi olmaktadır. Yeni öğretmenler çalışmalarının önemini anlamada ve çalışmalarını etkin ve tatmin edici bir şekilde sürdürmelerini sağlayacak kaynakları bulmak için yardıma ihtiyaç duyarlar (McCann ve Johannessen, 2014). Destekleyici bir kültüre ve açık bir iklime sahip okullarda yeni öğretmenler sorunların üstesinden gelmek için yeterli destek bulabilmekte ve kısa sürede mesleki bir kimlik kazanabilmektedir. Etkili okul araştırmaları ve okul liderliği literatüründe belirtildiği gibi, çevre aynı zamanda öğretmenlerin mesleki kariyerlerinde büyümelerine yardımcı olma ve öğretmenliğe olan bağlılıklarını sürdürmede önemli bir rol oynamaktadır (Lam, 2014). Adaylık dönemini bir kültürlenme süreci olarak değerlendiren Kozikoğlu ve Senemoğlu (2018), okul yönetimi ve kültürünün yeni öğretmenlerin öğrencilere yönelik tutumları ve meslekteki uygulamaları üzerindeki etkisi düşünüldüğünde, mesleğe yeni başlayan öğretmenlere uygun olanakların sağlanması ve tecrübeli öğretmenlerle işbirliği yapmalarının desteklenmesi gerektiğini ifade etmiştir. Smith \& İngersoll (2004) tarafindan yapılan araştırmada mentor öğretmenlerle desteklenen, diğer öğretmenlerle planlama ve işbirliği içerisinde olan aday öğretmenlerin diğer okullara gitme, mesleklerinin ilk yıllarında işten ayrılma olasılıklarının daha az olduğu sonucuna ulaşılmıştır. Okul müdürleri destekleyici bir okul kültürüne ve göreve yeni başlayan öğretmenlerin mesleki gelişimlerine önemli etki ederler. Bredeson ve Johansson'a (2000) göre okul müdürleri öğretim lideri olarak, bir öğrenme ortamının oluşturulması, mesleki gelişimin tasarımı, sunulması ve 
O.T. Çelik ve Ü. Kahraman/ Pamukkale Üniversitesi Eğitim Fakültesi Dergisi, 51, 179-205, 2021

içeriğini belirlenmesi ve son olarak değerlendirme açısından öğretmen öğrenmesinde önemli etkiye sahiptir. Bu kapsamda göreve yeni başlayan öğretmenler için okul kültürü, okul iklimi ve bunlar üzerinde önemli etkiye sahip olan okul müdürleri bir sorun kaynağ olabileceği gibi bir mesleki gelişim kaynağı da olabilir.

\section{Bireysel faktörlerin ve bă̆lamsal koşulların etkileşimi}

Göreve yeni başlayan öğretmenler için ortak problemler olsa da, yeni öğretmenlerin hepsi de aynı sorunları yaşamamaktadır. Yeni öğretmenlerin yaşadıkları sorunları sadece çevresel koşullarla açıklamak sınırlılıktır. Bu sentez altında bireysel faktörlerle çevre etkileşimi bir arada değerlendirilmiştir. Bireysel faktörler bazen karşılaşılan sorunların kaynağı olmakla birlikte çevreden kaynaklı sorunlarla başa çıkma ve direnç göstermede belirleyici olabilmektedir. Bu kapsamda öz yeterliği, uyum kapasitesi yüksek yeni öğretmenler sorunların üstesinden gelmede daha başarılı olmaktadır. Bullough'a (1989) göre de göreve yeni başlayan öğretmenlerin sorunlarla karşılaşıp karşılaşmamaları, kişisel özelliklerinin ve bağlamsal koşulların etkileşiminin sonucudur. Göreve yeni başlayan öğretmenin sınıfa getirdiği beceriler, anlayışlar ve tutumlar ile okul bağlamı öğretmenlerin ne gibi sorunlarla karşılaşılacağını belirler. Honng'un (2012) mesleği bırakanlarla göreve devam eden öğretmenlerin direnme tepkilerini karşılaştırdığı araştırmada, her iki grup benzer sorunları ifade etse de görevi bırakanların kendilerinde stres ve duygusal tükenmişlik yaratabilecek ağır yükler yükleyen inançlara sahip oldukları, göreve devam eden öğretmenlerin ise öğrencilerle ilişkilerinde sınırlar belirleyerek kendilerini zor duruma düşürecek durumlara karşı önlem alma eğiliminde oldukları belirlenmiştir. Ayrıca görevi bırakan öğretmenlerin istenmeyen öğrenci davranışları ve sınıf yönetimi sorunlarıyla karşılaştıklarında kişilik özelliklerine atıfta bulundukları ve buna bağlı olarak özyeterlik inançlarında azalma yaşadıkları, göreve devam eden öğretmenlerin ise yöneticilerin desteği ve yardımıyla güçlü özyeterlik inançlarını sürdürdükleri belirlenmiştir. Nitekim Meristo ve Eisenschmidt (2014) tarafından yapılan araştırmada da okul ikliminin ve yöneticilerden desteğin göreve yeni başlayan öğretmenlerin özyeterlik inançlarını etkilediği belirlenmiştir. Sonuç olarak göreve yeni başlayan öğretmenlerin özyeterlik algısı, sorunlarla başa çıkma kapasitesi, mesleğe ilişkin bilgi ve beceri düzeyleri ve uyum kapasiteleri hem sorun kaynağı hem de sorunlarla başa çıkmada önemli faktörler olduğu söylenebilir.

\section{Sonuç ve Öneriler}

Öğretmen eğitim programından mezun olarak göreve yeni başlayan öğretmenler, pedagojik bilgilerini öğretim ve müfredatla ilgili bilgilerini uygulamaya dönüştürmeye çalışırlar. 
Ancak öğretmen adayları göreve başladıklarında gerçeklik şoku dâhil birçok sorunla karşı karşıya kalarak çeşitli güçlükler yaşarlar. Acemi öğretmenlerin bu dönemdeki deneyimleri mesleki doyumlarını, bağlılıklarını, mesleki bir kimlik oluşturmalarını, mesleki becerilerini geliştirmeleri ve mesleğe verimli bir şekilde devam edip etmelerini önemli ölçüde belirler. $\mathrm{Bu}$ kapsamda göreve yeni başlayan öğretmenlerin yaşadıkları sorun alanlarının ve kaynaklarının belirlenmesi alınacak önlemler ve geliştirilecek politikalar için son derece önemlidir. İlgili literatürde mesleğin ilk yıllarında öğretmenlerin karşılaşmış olduğu genel sorunlara ve daha spesifik yönlerine odaklanmış farklı ülkelerde birçok araştırma bulunmaktadır. Yaşanılan kültür, bölge ve içerisinde bulunulan eğitim sistemi her ne kadar farklı olsa da ilgili literatür benzer sorunlara işaret etmektedir. Bu kapsamda bu araştırmada öğretmenlerin mesleğin ilk yıllarında karşılaştıkları sorunları konu edinen nitel yöntemlerin kullanıldığı araştırma sonuçları bir araya getirilerek sentezlenmiştir.

Araştırma sonucunda öğretmenlerin sorun alanlarını ifade eden altı tema belirlenmiştir. Bunlar; resmi politikalar ve okuldaki uygulamalar, sosyal ilişkiler, öğretim uygulamaları, destek, bireysel faktörler, okul ve çevreye uyumudur. Bu temalar sorun alanlarını ifade etse de çözüm amaçlı geliştirilecek politikalarda sorunların asıl kaynağı daha önemli hale gelmektedir. Araştırmada ikinci düzey bir soyutlamayla sorunların asıl kaynağına yönelik üç sentez elde edilmiştir. Bunlar; teori ve uygulama uyumsuzluğu, okul ve çevre bağlamı son olarak da bireysel faktörlerin ve bağlamsal koşulların etkileşimidir. Araştırmadan elde edilen sentezler başlıklar halinde ilgili literatüre dayalı olarak tartışılarak açıklanmıştır. Son olarak araştırmanın sonucuna ve meta senteze dahil edilen çalışmalardaki sonuçlar, öneriler, bulgu ve yorumlardan elde edilen sentezlere dayalı olarak aşağıdaki öneriler geliştirilmiştir. $\mathrm{Bu}$ öneriler, göreve yeni başlayan öğretmenlerin yaşadıkları sorunları azaltmaya ve mesleğe uyumlarını kolaylaştırmaya dönük uygulama ve politika ağırlıklı önerilerdir.

\section{Uygulamaya dönük öneriler}

- Öğretmen yetiştirme kurumlarının eğitim öğretimin gerçeklerine uygun eğitim vermesi,

- Teorik ve pratiği birbirine yakınlaştırmak, öğretmen adaylarının öz yeterlik algılarını arttırmak için hizmet öncesi dönemde uygulamalı eğitimlere ağırlık vermek, 
- Öğretmen eğitiminde, öğretmenlerin karşılaşacakları zorluklar konusunda ve öğretmenlerin (öğretmen adaylarının) kendilerini geliştirmeleri için üniversitelerle işbirliği yapilmak,

- Göreve yeni başlayan öğretmenlere zor sınıflar ve tam zamanlı görevlendirmeler vermemek; bu öğretmenlerin iş yükünü hafifleterek kendilerini geliştirebilmeleri için zaman birakmak,

- Öğretmenlere mesleğin ilk yıllarında karşılaşılan genel sorunlar ve kendi konu alanlarındaki sorunlara yönelik eğitim vermek,

- Göreve yeni başlayan öğretmenlerin öğrencilerle ve meslektaşlarıyla olumlu ilişkiler geliştireceği olanaklar sunmak,

- İlk görev yeri olarak öğretmenleri zorlu koşulların olduğu yerlere göndermek yerine, mesleğe uyum sağladıktan ve deneyim kazandıktan sonra zorlu koşulların bulunduğu yerlerde görev vermek.

- Okul yöneticileri hem bir lider hem bir mentör olarak aday öğretmenlerin mesleki gelişimine katkı sunacak uygulamalar ve olanaklar geliştirmesi.

\section{Politika ăğırlıkl öneriler}

- Okullarda destek kültürü, anlamlı ve şeffaf ilişkiler geliştirecek başlangıç eğitim programları geliştirmek,

- Etkin mentörlük uygulamaları geliştirmek,

- Yeni öğretmenlerin işbirlikçi faaliyetlerini destekleyecek, özel ihtiyaçlarını dile getirecek ve kendi görüşlerinin duyulmasını sağlayacak mekanizmalar geliştirmek,

- Yeni öğretmenlerin ihtiyaçlarına duyarlı, bilgi ve deneyimlerini paylaşabilecekleri mesleki öğrenme topluluğu uygulamaları geliştirmek. 


\section{Kaynakça}

Aitken, R.,\& Harford, J. (2011). Induction needs of a group of teachers at different career stages in a school in the Republic of Ireland: Challenges and expectations. Teaching and Teacher Education, 27(2), 350-356.

Alhija, F. N. A.,\& Fresko, B. (2010). Socialization of new teachers: Does induction matter?. Teaching and Teacher Education, 26(8), 1592-1597.

Aydın, İ. (2018). Teacher career cycles and teacher professional development. Journal of Human Sciences, 15(4), 2047-2065.

Bakioğlu, A. (1996). Öğretmenlerin kariyer evreleri. II. Ulusal Eğitim Bilimleri Sempozyumu Bildiri Metinleri, M.U Atatürk Eğitim Fakültesi Yayınları.

Boakye, C.,\& Ampiah, J. G. (2017). Challenges and solutions: the experiences of newly qualified science teachers. SAGE Open, 7(2), 1-10.

Bondas, T.,\& Hall, E. O. (2007). Challenges in approaching metasynthesis research. Qualitative Health Research, 17(1), 113-121.

Bredeson, P. V. \& Johannson, O. (2000). The school principal's role in teacher professional development. Journal of In-Service Education, 26(2), 385-401.

Bullough, R. V. (1989). Teacher education and teacher reflectivity. Journal of Teacher Education, 40(2), 15-21.

Cantú, M.,\& Martínez, N. H. (2006). Problems faced by beginning teachers in private elementary schools: A comparative study between Spain and Mexico. Revista Electrónica de Investigación Educativa, 8(2), 1-16.

Caspersen, J.,\& Raaen, F. D. (2014). Novice teachers and how they cope. Teachers and Teaching, 20(2), 189-211.

Creswell, J. W. (2007). Qualitative inquiry and research design: choosing among five approaches $\left(2^{\text {nd }}\right.$. Ed.). London: Sage Publications.

Darling-Hammond, L. (2003). Keeping good teachers: Why it matters, what leaders can do. Educational Leadership, 60(8), 6-13.

Dias-Lacy, S. L.,\& Guirguis, R. V. (2017). Challenges for new teachers and ways of coping with them. Journal of Education and Learning, 6(3), 265-272. 
O.T. Çelik ve Ü. Kahraman/ Pamukkale Üniversitesi Eğitim Fakültesi Dergisi, 51, 179-205, 2021201

Dickson, M., Riddlebarger, J., Stringer, P., Tennant, L., \& Kennetz, K. (2014). Challenges faced by Emirati novice teachers. Near and Middle Eastern Journal of Research in Education, 4, 1-10.

Dropkin, S.,\& Taylor, M. (1963). Perceived problems of beginning teachers and related factors. Journal of Teacher Education, 14(4), 384-390.

Fantilli, R. D.,\& McDougall, D. E. (2009). A study of novice teachers: Challenges and supports in the first years. Teaching and Teacher Education, 25(6), 814-825.

Feiman-Nemser, S. (2001). From preparation to practice: Designing a continuum to strengthen and sustain teaching. Teachers College Record, 103, 1013-1055.

Fetherston, T.,\& Lummis, G. (2012). Why Western Australian secondary teachers resign. Australian Journal of Teacher Education, 37(4), 1-20

Fottland, H. (2004). Memories of a fledgling teacher: a beginning teacher's autobiography. Teachers and Teaching, 10(6), 639-662.

Gaikhorst, L., Beishuizen, J., Roosenboom, B., \& Volman, M. (2017). The challenges of beginning teachers in urban primary schools. European Journal of Teacher Education, 40(1), 46-61.

Gömleksiz, M. N., Kan, A. Ü., Biçer, S., ve Yetkiner, A. (2010). Mesleğe yeni başlayan sınıf öğretmenlerinin yaşadıkları zorluklarla öğretmen adaylarının yaşayabilecekleri zorluklara ilişkin algılarının karşılaştırılması. E-Journal of New World Sciences Academy, 5(3), 12-23.

Gujarati, J. (2012). A comprehensive induction system: A key to the retention of highly qualified teachers. The Educational Forum, 76(2), 218-223).

Gülay, A., ve Altun, T. (2017). Göreve yeni başlayan öğretmenlerin yeterlik algılarının ve karşılaştıkları sorunların belirlenmesi. Dicle University Journal of Ziya Gokalp Education Faculty, 31, 738-749.

Hayes, D.,\& Chang, K. (2017). South Korean novice English language teachers' experience of 1nduction into teaching. English Teaching, 72(1), 49-71.

Helms-Lorenz, M., Van de Grift, W., \& Maulana, R. (2016). Longitudinal effects of induction on teaching skills and attrition rates of beginning teachers. School Effectiveness and School Improvement, 27(2), 178-204. 
Hong, J. Y. (2012). Why do some beginning teachers leave the school, and others stay? Understanding teacher resilience through psychological lenses. Teachers and Teaching, 18(4), 417-440.

Huberman, M. A. (1989). The professional life cycle of teachers. Teachers College Record, 91(1), 31-57.

Ingersoll, R. (2012) Beginning teacher induction: what the data tell us. Phi Delta Kappan, 93(8), 47-51

Ingersoll, R. M.,\& Strong, M. (2011). The impact of induction and mentoring programs for beginning teachers: A critical review of the research. Review of Educational Research, 81(2), 201-233.

Kelchtermans, G.,\& Ballet, K. (2002). The micropolitics of teacher induction. A narrativebiographical study on teacher socialisation. Teaching and Teacher Education, 18(1), 105-120.

Kelly, N., Reushle, S., Chakrabarty, S., \& Kinnane, A. (2014). Beginning teacher support in Australia: Towards an online community to augment current support. Australian Journal of Teacher Education, 39(4), 68-82.

Kozikoğlu, İ.,\& Senemoğlu, N. (2018). Öğretmenlik mesleğine adanmışlık ölçeğinin geliştirilmesi: Geçerlik ve güvenirlik çalışması [Development of teachers' professional engagement scale: A study on validity and reliability]. Journal of Human Sciences, 15(4), 2614-2625.

Korkmaz, İ., Akbaşlı, S., ve Saban, A. (2004). Göreve yeni başlayan sınıf öğretmenlerinin karşılaştıkları güçlükler. Kuram ve Uygulamada Egitim Yönetimi Dergisi, 10(2), 266-277.

Kuzmic, J. (1994). A beginning teacher's search for meaning: Teacher socialization, organizational literacy, and empowerment. Teaching and Teacher Education, 10(1), $15-27$.

Lam, B. H. (2014). Challenges beginning teachers face in Hong Kong. Schools, 11(1), 156169.

Long, J. S., McKenzie-Robblee, S., Schaefer, L., Steeves, P., Wnuk, S., Pinnegar, E., \& Clandinin, D. J. (2012). Literature review on induction and mentoring related to early 
O.T. Çelik ve Ü. Kahraman/ Pamukkale Üniversitesi Eğitim Fakültesi Dergisi, 51, 179-205, 2021203

career teacher attrition and retention. Mentoring \& Tutoring: Partnership in Learning, 20(1), 7-26.

Lortie, D. (1975). Schoolteacher: A sociological study. Chicago, IL: University of Chicago Press.

Löfström, E.,\& Eisenschmidt, E. (2009). Novice teachers' perspectives on mentoring: The case of the Estonian induction year. Teaching and Teacher Education, 25(5), 681689.

Merriam, S. B. (2009). Qualitative research: a guide to design and implementation (2 nd. Ed.). San Francisco: Josey Bass.

Meristo, M.,\& Eisenschmidt, E. (2014). Novice teachers' perceptions of school climate and self-efficacy. International Journal of Educational Research, 67, 1-10.

Mudzingwa, K.,\& Magudu, S. (2013). Idealism versus realism: Expectations and challenges of beginning teachers in three districts of Masvingo Province, Zimbabwe. Journal of Studies in Social Sciences, 3(1), 33-54.

McCann, T. M.,\& Johannessen, L. R. (2004). Why do new teachers cry?. The Clearing House: A Journal of Educational Strategies, Issues and Ideas, 77(4), 138-145.

Neuman, W. L. (2011). Social research methods: Qualitative and quantitative approaches. Boston: Pearson/Allyn and Bacon.

Nieme, H. (2002) Active learning - a cultural change needed in teacher education and schools. Teaching and Teacher Education, 18(7), 763-780.

Noah Jr, P. D. (2017). A systematic approach to the qualitative meta-synthesis. Issues in Information Systems, 18(2), 196-205. Retrieved from http://www.iacis.org/iis/2017/2_iis_2017_196-205.pdf

Noblit, G. W.,\& Hare, R. D. (1988). Meta-ethnography: Synthesizing qualitative studies. London: Sage Publications.

Önder, E. (2018). Aday öğretmen görüşlerine göre aday öğretmen yetiştirme programı [Prospective teacher training program according to prospective teachers' opinions]. Kuram ve Uygulamada Ĕ̈itim Yönetimi, 24(1), 143-189.

Öztürk, M. (2016). Köy ve kasabalarda görev yapan öğretmenlerin mesleğin ilk yılında yaşadıkları güçlükler. İlkögrretim Online, 15(2), 378-390. 
Ritchie, J. S.,\& Wilson, D. E. (1993). Dual apprenticeships: Subverting and supporting critical teaching. English Education, 25(2), 67-83.

Sandelowski, M., Barroso, J., \& Voils, C. I. (2007). Using qualitative metasummary to synthesize qualitative and quantitative descriptive findings. Research in Nursing \& Health, 30(1), 99-111. https://doi.org/10.1002/nur.20176.

Sandelowski, M., Docherty, S., \& Emden, C. (1997). Focus on qualitative methods Qualitative metasynthesis: issues and techniques. Research in Nursing and Health, $20,365-372$.

Sandlin, R. A., Young, B. L., \& Karge, B. D. (1993). Regularly and alternatively credentialed beginning teachers: Comparison and contrast of their development. Action in Teacher Education, 14(4), 16-23.

Schuck, S., Aubusson, P., Buchanan, J., \& Russell, T. (2012). Beginning teaching: Stories from the classroom. Springer Science \& Business Media.

Smith, H. P. (1950). Study of the problems of beginning teachers. Educational Administration and Supervision, 36, 257-264.

Smith, T. M.,\& Ingersoll, R. M. (2004). What are the effects of induction and mentoring on beginning teacher turnover?. American Educational Research Journal, 41(3), 681714.

Stout, J. B. (1952). Deficiencies of beginning teachers. Journal of Teacher Education, 3(1), 43-46.

Temiz, Z. (2017). Yeni okul öncesi öğretmenlerinin yaşadiklari zorluklar ve öğretmen adaylarinin kaygilari. Mersin Üniversitesi Eğitim Fakültesi Dergisi, 13(3), 871-885.

Tyack, D. (1974). The one best system. Cambridge, MA: Harvard University Press

Ulubey, Ö. (2018). Evaluation of novice teacher training program. H. U. Journal of Education, 33(2), 480-502.

Ulvik, M., Smith, K., \& Helleve, I. (2009). Novice in secondary school-the coin has two sides. Teaching and Teacher Education, 25(6), 835-842.

Valeeva, R., Baklashova, T., \& Latypova, L. (2018). Management of novice teachers' induction to the profession: Modernization of the Russian school methodological system. Journal of e-Learning and Knowledge Society, 14(2), 39-50. 
O.T. Çelik ve Ü. Kahraman/ Pamukkale Üniversitesi Eğitim Fakültesi Dergisi, 51, 179-205, 2021205

Varah, L. J., Theune, W. S., \& Parker, L. (1986). Beginning teachers: Sink or swim?. Journal of Teacher Education, 37(1), 30-34.

Veenman, S. (1984). Perceived problems of beginning teachers. Review of Educational Research, 54(2), 143-178.

Vonk, J. (1989). Becoming a teacher, brace yourself. Unpublished paper. Vrije University, Amsterdam.

Weed, M. (2005). "Meta interpretation": A method for the interpretive synthesis of qualitative research. Forum: Qualitative Social Research, 6(1), 1-21. http://dx.doi.org/10.17169/fqs-6.1.508

Zetlin, A., MacLeod, E., \& Kimm, C. (2012). Beginning teacher challenges instructing students who are in foster care. Remedial and Special Education, 33(1), 4-13. 